\title{
Analisis Laporan Keuangan Untuk Menilai Kinerja Keuangan PT. Surya Citra Media Tbk.
}

\author{
Fakung Rahman ${ }^{1)}$ dan R. Chepi Safei Jumhana ${ }^{2)}$ \\ ${ }^{1,2)}$ Dosen Universitas Pamulang, fakungrachman@yahoo.com
}

\section{ARTICLES \\ INFORMATION}

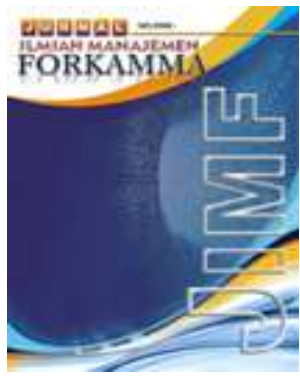

\section{JURNAL ILMIAH MANAJEMEN FORKAMMA}

Vol.3, No.2, Maret 2020

Halaman : $150-160$

(c) LPPM \& FORKAMMA

Prodi Magister Manajemen

UNVERSITAS PAMULANG

ISSN (online) : 2599-171X

ISSN (print) : :2598-9545

\section{Keyword :}

Liquidity ratio, profitability ratio, activity ratio and solvency ratio

JEL. classification :

A11,

\section{Contact Author :}

PRODI

MAGISTER MANAJEMEN \& FORKAMMA UNPAM

JL.Surya Kencana No.1 Pamulang

Tangerang Selatan - Banten

Telp. (021) 7412566, Fax (021) 7412491

Email :

jurnalforkamma.unpam@gmail.com
Walaupun sudah banyak orang yang meneliti tentang kinerja keuangan suatu perusahaan, akan tetapi sangat jarang bahkan mungkin belum ada orang yang meneliti kinerja keuangan perusahaan di bidang industri jasa penyiaran (televisi), maka dari itu penulis tertarik untuk meniliti kinerja keuangan PT. Surya Citra Media Tbk. (SCMA), yang kebetulan perusahaan tersebut sebagai holding dari dua stasiun televisi ternama yaitu PT. Surya Citra Televisi (SCTV) dan PT. Indosiar Visual Mandiri (Indosiar).

Adapun tujuan dari penelitian ini adalah untuk mengetahui kinerja keuangan PT. Surya Citra Media Tbk. berdasarkan analisis rasio likuiditas, rentabilitas, aktivitas dan rasio solvabilitas. Fokus dalam penelitian ini adalah kinerja keuangan yang dapat diukur dengan 13 rasio keuangan yaitu Current Ratio, Quick Ratio, Cash Ratio, Total Asset Turnover, Fixed Asset Turnover, Working Capital Turnover, Inventory Turnover, Debt to Equity Ratio, Debt to Asset Ratio, Gross Profit Margin, Return on Asset, dan Return on Equity.

Although many people have researched the financial performance of a company, but it is very rare that there may not even be anyone who has examined the financial performance of a company in the broadcasting service industry (television), therefore the authors are interested in examining the financial performance of PT. Surya Citra Media Tbk. (SCMA), which happens to be the holding company of two well-known television stations namely PT. Surya Citra Televisi (SCTV) and PT. Indosiar Visual Mandiri (Indosiar).

The purpose of this study is to determine the financial performance of PT. Surya Citra Media Tbk. based on the analysis of liquidity ratios, profitability, activity and solvency ratios. The focus in this research is financial performance that can be measured by 13 financial ratios namely Current Ratio, Quick Ratio, Cash Ratio, Total Asset Turnover, Fixed Asset Turnover, Working Capital Turnover, Inventory Turnover, Debt to Equity Ratio, Debt to Asset Ratio, Gross Profit Margin, Return on Assets and Return on Equity. 


\section{A. PENDAHULUAN}

Pada umumnya pendirian sebuah perusahaan bertujuan untuk meningkatkan nilai perusahaan tersebut, memakmurkan pemegang saham dan memiliki kinerja yang konsisten selama perusahaan tersebut berdiri. Laba atau keuntungan merupakan selisih dari pendapatan setelah dikurangi dengan biaya-biaya (costs) yang terjadi pada operasional perusahaan dalam periode tertentu. Laba perusahaan tidak hanya sematamata dimanfaatkan untuk menjaga operasional dan meningkatkan nilai perusahaan, namun pada laba perusahaan juga diberikan kepada pemegang saham sebagai deviden dan tambahan kompensasi tambahan kepada karyawan atas hasil pekerjaannya yang baik dan menguntungkan bagi perusahaan. Dengan demikian laba perusahaan dapat dikatakan sebagai salah satu tolok ukur untuk menilai bahwa perusahaan tersebut berhasil atau tidak. Selain laba sebagai alat ukur untuk minilai tingkat keberhasilan dari investasi para pemegang saham, kinerja yang konsisten juga termasuk dalam indikator keberhasilan suatu perusahaan.

Menurut Wirawan Suryanto (2019) : "Keberhasilan sebuah perusahaan dapat dilihat dari hasil kinerja keuangan yang dihasilkan selama suatu periode tertentu, informasi mengenai kinerja keuangan memiliki peranan yang penting juga sangat diperlukan oleh masyarakat luas umumnya, khususnya bagi calon investor. Investor dan masyarakat dapat mengukur keberhasilan dan kinerja dari suatu perusahaan pada suatu masa melalui hasil dari laporan keuangan yang diumumkan oleh perusahaan yang telah go public baik melalui website-nya perusahaan maupun laman PT. Bursa Efek Indonesia (www.idx.co.id)".

Informasi atau gambaran tentang kondisi dan perkembangan sebuah perusahaan menurut Sawir, Agnes (2001:2) yang dikutip oleh Puspitaningtyas, Dionisia Domasrani (2014) adalah "laporan keuangan yang disusun setiap akhir periode sebagai laporan pertanggungjawaban suatu perusahaan. Laporan keuangan yang terdiri dari neraca, laporan laba-rugi, laporan perubahan modal, dan laporan arus kas yang dikeluarkan oleh perusahaan merupakan suatu bentuk laporan pertanggungjawaban dari pihak manajemen terhadap pihak intern perusahaan terutama para pemegang saham maupun pihak ekstern perusahaan yaitu para investor, pemerintah dan pihak lain yang berkepentingan sehingga dapat dinilai kinerja perusahaan pada umumnya dan kinerja manajer pada khususnya".

Oleh karena begitu sangat pentingnya sebuah laporan keuangan perusahaan bagi berbagai pihak terutama untuk investor maupun kreditur, maka pihak manajemen perusahaan sebagai pihak yang paling bertanggungjawab atas terbitnya sebuah laporan keuangan yang sudah dirilis dalam penyajiannya harus dalam bentuk yang wajar, akuntabel, valid dan juga dapat diuji kebenarannya. Berbagai pihak yang mempunyai kepentingan dengan sebuah laporan keuangan terutama pemerintah, investor maupun calon investor sampai saat ini laporan keuangan masih digunakan sebagai pedoman atau tolok ukur untuk diambilnya sebuah keputusan yang berkaitan dengan penilaian terhadap kinerja perusahaan. Karena dari laporan keuangan akan dilakukan analisis terhadap pospos keuangan tertentu. Pada umumnya para analis dalam melakukan analisis laporan keuangan menggunakan analisa rasio, baik rasio likuiditas, rasio rentabilitas, maupun rasio solvabilitas.

Adapun tujuan dari penelitian ini yaitu untuk mengetahui kinerja keuangan PT. Surya Citra Media Tbk. berdasarkan analisis rasio likuiditas, rentabilitas, solvabilitas dan rasio profitabilitas. Dan dalam penilitian ini, peniliti menggunakan data sekunder yaitu berupa laporan keuangan PT. Surya Citra Media Tbk. untuk periode tahun 2014 sampai dengan tahun 2018.

Dengan hasil penelitian ini penulis berharap bisa menambah wawasan para kolega dosen dalam penelitian di bidang akuntansi dan keuangan. Begitu pula penulis 
juga berharap agar hasil penelitian ini bisa digunakan sebagai acuan para mahasiswa yang akan melakukan penulisan skripsi.

\section{B. TINJAUAN PUSTAKA}

Penilaian kinerja (performance appraisal) adalah tindakan evaluasi secara sistematis terhadap kinerja (dalam hal ini manajemen) dan untuk menilai apakah keterampilan, kemampuan serta ada peningkatan dari karyawan dalam menunaikan tugas serta tanggung-jawabnya yang diembannya sehingga menghasilkan kinerja seperti yang seperti yang sudah ditetapkan oleh perusahaan.

Difinisi dari penilaian kinerja menurut Hasibuan (2000:87) bahwa: "Penilaian kinerja adalah kegiatan manajer untuk mengevaluasi perilaku prestasi kerja pegawai serta menetapkan kebijaksanaan selanjutnya. Evaluasi atau penilaian perilaku meliputi penilaian kesetiaan, kejujuran, kepemimpinan, kerjasama, loyalitas, dedikasi, dan partsipasi pegawai".

Sedangkan Handoko (1994:11) menyatakan bahwa: "Penilaian kinerja merupakan cara pengukuran kontribusi-kontribusi dari individu dalam organisasi. Nilai penting dari penilaian kinerja adalah menyangkut penentuan tingkat kontribusi individu atas kinerja yang diekspresikan dalam penyelesaian tugas-tugas yang menjadi tanggung jawabnya".

Pada hakekatnya penilaian kinerja merupakan penilaian atas perilaku, kemampuan dan prestasi karyawan dalam melaksanan visi, misi dan tujuan perusahaan (organisasi). Adapun tujuan dari penilaian kinerja karaywan/manajemen adalah sebagai berikut:

1. Sebagai tolok ukur untuk menentukan besarnya kompensasi, remunerasi, kenaikan gaji/upah, promosi dan sebagainya.

2. Untuk melakukan identifikasi kekuatan (strength) dan kelemahan (weakness) karyawan sehingga manajemen dapat mengambil keputusan yang tepat memposisikan seorang karyawan tempat/pekerjaan (job) yang tepat.

3. Untuk memberikan penilaian terhadap potensi dari karyawan, sehingga dapat dibuat perencanaan untuk pengembangan karir yang lebih tinggi dari karyawan yang dilakukan appraisal.

4. Sebagai umpan balik (feedback) bagi karyawan atas kinerjanya selama ini.

5. Untuk membuat kebijakan berkaitan dengan kebiasaan dan kinerja karyawan.

6. Untuk memberikan kesempatan karyawan yang berprestasi dalam pengembangan kariernya dan untuk menyusun program pelatihan karyawan.

Kinerja keuangan merupakan hasil kerja dari berbagai departemen yang ada di dalam sebuah perusahaan. Hal ini tercermin / terlihat pada posisi atau kondisi keuangan perusahaan dalam satu periode tertentu terkait dengan aspek pendanaan baik dalam menghimpun dana maupun dalam penggunaan dana yang penilaiannya didasarkan pada indikasi kecukupan modal, likuiditas (liquidity), dan profitabilitas (profitability) perusahaan. Kinerja keuangan juga bisa diartikan melihat sudah sejauh mana perusahaan telah melakukan pembukuaanya berdasarkan standar akuntansi keuangan yang berlaku di Indonesia dalam hal ini sesuai dengan Generally Accepted Accounting Principles (GAAP) maupun sesuai dengan Pernyataan Akuntansi Keuangan (PAK) yang disusun oleh Ikatan Akuntan Indonesia (IAI) dan mengikuti peraturan-peraturan pemerintah.

Sedangkan kinerja keuangan menurut Lutfi dan Sunardi (2019:90) adalah "suatu perusahaan sangat erat kaitannya dengan penilaian mengenai sehat atau tidak sehatnya perusahaan tersebut.Apabila tingkat kinerjanya baik, maka baik pula tingkat kesehatan perusahaan". Menurut Mulyadi (2012:20) "Kinerja keuangan adalah penentuan secara periodik efektifitas operasional suatu oerganisasi berdasarkan sasaran, standard dan criteria yang ditetapkan". Sedangkan Fahmi (2012:2) menjelaskan "Kinerja keuangan adalah analisis yang dilakukan untuk melihat sejauh mana suatu perusahaan telah melaksanakan dengan menggunakan aturan-aturan pelakasanaan keuangan secara baik dan benar". Sedangkan Sawir berpendapat (2012:15) "Kinerja keuangan adalah kondisi 
yang mencerminkan keadaan keuangan suatu perusahaan berdasarkan sasaran, standar dan kinerja yang ditetapkan". Adapun Rudianto (2013:189) berpendapat "Kinerja keuangan adalah hasil atau prestasi yang telah dicapai oleh manajemen perusahaan dalam mengelola aset perusahaan secara efektif selama periode tertentu. Kinerja keuangan sangat dibutuhkan oleh perusahaan untuk mengetahui dan mengevaluasi tingkat keberhasilan perusahaan berdasarkan aktivitas keuangan yang telah dilaksanakan".

Hasil dari pengukuran kinerja keuangan perusahaan bagi manajemen dipakai sebagai landasan dalam mengambil keputusan dan kebijakan di dalam perusahaan. Pengukuran kinerja keuangan di perusahaan tergantung dari sudut pandang yang diambil dan tujuan dari analisis. Karena alasan tersebut, pihak manajemen perusahaan harus melakukan menyesuaikan kondisi dan posisi perusahaan dengan hasil penilaian kinerja yang sudah didapat demi kemajuan perusahaan kedepannya..

Munawir mengatakan (2004:31), "bahwa ada empat tujuan dilaksanakannya pengukuran kinerja keuangan perusahaan yakni untuk:

1. Mengetahui tingkat likuiditas, yaitu kemampuan perusahaan dalam memenuhi kewajiban keuangan yang harus segera diselesaikan pada saat ditagih.

2. Mengetahui tingkat solvabilitas, yaitu kemampuan perusahaan untuk memenuhi kewajiban keuangannya apabila perusahaan tersebut dilikuidasi, kewajiban keuangan yang dimaksud mencakup keuangan jangka pendek maupun jangka panjang.

3. Mengetahui tingkat profitabilitas atau rentabilitas, yaitu kemampuan perusahaan dalam menghasilkan laba selama periode tertentu dengan menggunakan aktiva atau modal secara produktif.

4. Mengetahui tingkat stabilitas, yaitu kemampuan perusahaan dalam menjalankan dan mempertahankan usahanya sehingga tetap stabil. Kemampuan yang dimaksud diukur dari kemampuan perusahaan membayar pokok hutang dan beban bunga tepat pada waktunya".

\section{METODOLOGI PENELITIAN}

Dalam penelitian ini, peneliti menggunakan metode penelitian kualitatif seperti yang diuraikan oleh Raco (2010:56) dimana : "metode kualitatif memiliki beberapa sifat khasnya, yaitu penekanan pada lingkungan yang alamiah (naturalistic setting), induktif (inductive), fleksibel (flexible), pengalaman langsung (direct experience), kedalaman (indepth), proses, menangkap arti (verstehen), keseluruhan (wholeness), partisipasi aktif dari partisipan dan penafsiran (interpretation)".

Ada beberapa keunggulan yang dimiliki dalam metode penelitian kualitatif (Raco, 2010 : 62-64), "yaitu :

1. Datanya sangat mendasar karena berdasarkan fakta, peristiwa dan realita. Jadi bukan merupakan rekayasa peneliti, peneliti masuk dalam konteks tempat penelitian tanpa prasangka, praduga, ataupun konsep, jadi peneliti tidak berapriori.

2. Pembahasannya mendalam dan terpusat, karena datanya digali secara mendalam. Keterlibatan peneliti dalam penelitian yang cukup lama dan memperhitungkan semua faktor yang mengitarinya seperti ideologi, politik, ekonomi, budaya menunjukkan kedalaman makna yang nantinya dihasilkan lewat metode ini.

3. Terbuka pada lebih dari satu pandangan dalam hal ini pandangan dan informasi dari partisipan. Hasil penelitian tidak diasumsikan oleh peneliti di awal penelitian, tetapi diperoleh dari partisipan dan dianalisa oleh peneliti. Informasi dan masukan dari partisipan menjadi rujukan utama analisis, ini menunjukkan aspek demokrasi dari metode ini.

4. Sifatnya yang realitis dari metode kualitatif ini, dimana peneliti menggunakan metode ini percaya kepada dinamika dan proses. Manusia dan alam lingkungan hidup, berkembang dan berubah dari waktu ke waktu. Realita yang tidak disangsikan yaitu 


\section{ISSN (print) : 2598-9545 \& ISSN (online) : 2599-171X

bahwa semuanya berubah, proses ini tidak pernah selesai, hal ini sangat diakomodir oleh metode kualitatif.

5. Keuntungan menggunakan metode kualitatif ini adalah : bila ingin mengetahui sesuatu secara mendalam, bila gejala kurang diketahui dan masih belum jelas, apalagi gejala tidak dapat diukur dan bila penelitian tidak dapat dibuat dengan eksperimen di laboratorium.

6. Metode kualitatif ini benar-benar menempatkan manusia sebagaimana mestinya, dimana manusia adalah makhluk yang sangat luhur, tidak ada duanya. Manusia tidak hanya berada tetapi mengerti keberadaannya, dapat berbicara, berpikir dan dapat menentukan masa depannya".

\section{Data Analisis}

Sumber data yang dipakai dalam penelitian ini adalah data sekunder (data yang sudah ada) yaitu dokumen berupa laporan keuangan PT. Surya Citra Media Tbk. yang sudah dirilis oleh perusahaan. Data dalam penelitian ini, adalah data sekunder berupa dokumen yang diperoleh dari PT. Bursa Efek Indonesia (www.idx.co.id) malalui website yang berkaitan dengan penelitian ini. Data atau dokumen yang digunakan dalam penelitian ini didapat dari laporan keuangan PT. Surya Citra Media Tbk. untuk periode tahun 2014 sampai dengan bulan tahun 2018 .

\section{Metode Analisis Data}

Metode analisa yang digunakan adalah metode analisa horizontal. Kasmir (2008:69) menyatakan metode analisa horizontal yaitu "membandingkan laporan keuangan untuk beberapa periode. Dari hasil analisis ini akan terlihat perkembangan perusahaan dari periode satu ke periode yang lain". Munawir, dikutip dalam Faizal (2008:41) menyatakan "dalam menganalisa dan menilai posisi keuangan dan potensi atau kemajuan-kemajuan perusahaan, faktor-faktor utama yang harus diperhatikan oleh penganalisa adalah rasio likuiditas, rasio solvabilitas, rasio aktivitas dan rasio profitabilitas".

\section{Kerangka Berpikir}

Pada dasarnya dilakukan penelitian ini untuk meneliti adanya perubahan /pergerakan kenerja keuangan PT. Surya Citra Media Tbk. untuk periode tahun 20142018 dengan menggunakan liquidity ratio, activity ratio, solvency ratio, dan profitability ratio. Adapun kerangka berpikir dalam penelitian ini seperti pada gambar dibawah ini:

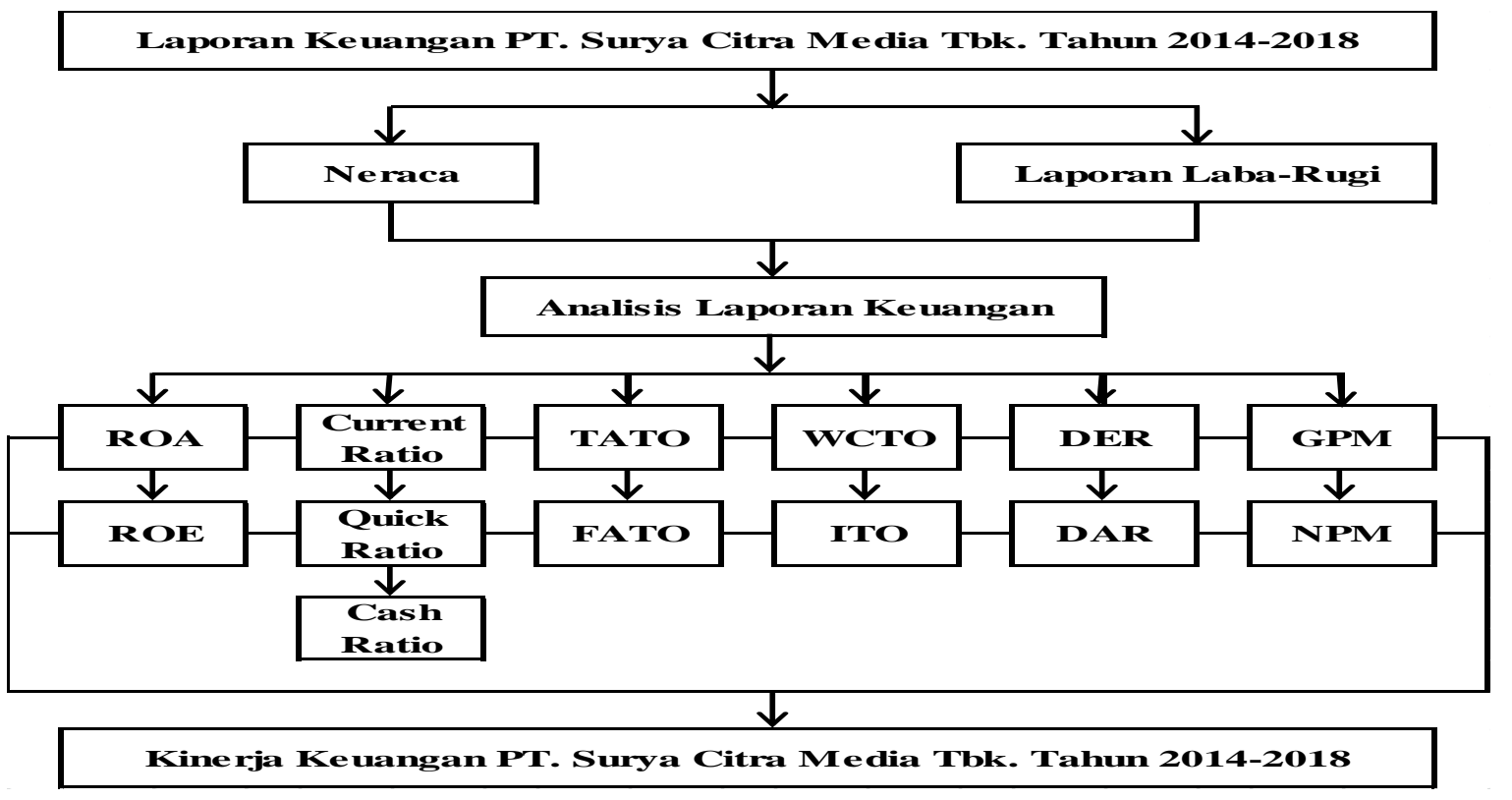




\section{HASIL DAN PEMBAHASAN}

Data yang dianalisis adalah data laporan keuangan PT. Surya Citra Media Tbk. (SCMA) yang terdiri dari neraca dan laporan laba-rugi. Analisa rasio keuangan yang digunakan untuk menilai kinerja keuangan PT. Surya Citra Media Tbk. meliputi rasio likuiditas, aktivitas, solvabilitas, dan profitabilitas, berikut adalah hasil analisanya :

1. Current Ratio PT. Surya Citra Media Tbk. Tahun 2014-2018 (dalam Ribuah Rupiah) :

\begin{tabular}{|c|c|r|c|c|c|r|c|}
\hline \multirow{2}{*}{ Tahun } & \multirow{2}{*}{ Aktiva Lancar } & \multirow{2}{*}{ Utang Lancar } & \multirow{2}{*}{ CR $(\%)$} & \multicolumn{4}{|c|}{ Kenaikan / Penurunan } \\
\cline { 5 - 8 } & & & & Aktiva Lancar & $\%$ & Utang Lancar & $\%$ \\
\hline 2014 & 3.204 .742 .572 & 818.040 .442 & 391,76 & & & & \\
\hline 2015 & 2.843 .499 .538 & 860.469 .667 & 330,46 & $(361.243 .034)$ & $(11,27)$ & 42.429 .225 & 5,19 \\
\hline 2016 & 2.952 .180 .869 & 990.467 .600 & 298,06 & 108.681 .331 & 3,82 & 129.997 .933 & 15,11 \\
\hline 2017 & 2.708 .606 .433 & 743.336 .338 & 364,39 & $(243.574 .436)$ & $(8,25)$ & $(247.131 .262)$ & $(24,95)$ \\
\hline 2018 & 3.426 .795 .184 & 804.149 .297 & 426,14 & 718.188 .751 & 26,52 & 60.812 .959 & 8,18 \\
\hline
\end{tabular}

2. Quick Ratio PT. Surya Citra Media Tbk. Tahun 2014-2018 (dalam Ribuah Rupiah) :

\begin{tabular}{|c|c|c|c|c|c|c|c|}
\hline \multirow{2}{*}{ Tahun } & \multirow{2}{*}{\begin{tabular}{|c|} 
Aktiva Lancar - \\
Persediaan
\end{tabular}} & \multirow{2}{*}{ Utang Lancar } & \multirow{2}{*}{ QR (\%) } & \multirow{2}{*}{$\begin{array}{l}\text { Aktiva Lancar - } \\
\text { Persediaan }\end{array}$} & \multicolumn{3}{|c|}{ Kenaikan / Penurunan } \\
\hline & & & & & $\%$ & Utang Lancar & $\%$ \\
\hline 2014 & 1.956.119.308 & 442 & 12 & & & & \\
\hline 2015 & 2.157 .777 & 67 & 250,77 & 36 & 10,31 & 25 & 5,19 \\
\hline 2016 & 2.262 .890 .202 & 990.467 & 228,47 & 105.112 .558 & 4,87 & 129.997 .933 & 15,11 \\
\hline 2017 & 1.942 .621 .623 & 743.336 .338 & 26 & $(320.268 .579)$ & $(14,15)$ & $(247.131 .262)$ & $(24,95)$ \\
\hline 2018 & 2.484 .093 .357 & 804.149 .297 & 308,91 & 541.471 .734 & 27,87 & 60.812 .959 & 8,18 \\
\hline
\end{tabular}

3. Cash Ratio PT. Surya Citra Media Tbk. Tahun 2014-2018 (dalam Ribuah Rupiah) :

\begin{tabular}{|c|r|r|c|c|c|r|c|}
\hline \multirow{2}{*}{ Tahun } & \multirow{2}{*}{ Kas + Efek } & \multirow{2}{*}{ Utang Lancar } & \multirow{2}{*}{\begin{tabular}{c} 
Cash Ratio \\
\cline { 6 - 8 }
\end{tabular}} & & \multicolumn{4}{|c|}{ Kenaikan / Penurunan } \\
\cline { 7 - 9 } & & & Kas + Efek & $\%$ & Utang Lancar & $\%$ \\
\hline 2014 & 1.248 .623 .264 & 818.040 .442 & 152,64 & & & & \\
\hline 2015 & 685.721 .894 & 860.469 .667 & 79,69 & $(562.901 .370)$ & $(45,08)$ & 42.429 .225 & 5,19 \\
\hline 2017 & 454.731 .888 & 990.467 .600 & 45,91 & $(230.990 .006)$ & $(33,69)$ & 129.997 .933 & 15,11 \\
\hline 2018 & 829.516 .750 & 743.336 .338 & 31,41 & $(221.215 .138)$ & $(48,65)$ & $(247.131 .262)$ & $(24,95)$ \\
\hline
\end{tabular}

4. Total Asset Turnover PT.Surya Citra Media Tbk. Tahun 2014-2018 (dalam Ribuah Rupiah):

\begin{tabular}{|c|c|c|c|c|c|c|c|}
\hline \multirow{2}{*}{ Tahun } & \multirow{2}{*}{ Penjualan Netto } & \multirow{2}{*}{ Jumlah Aktiva } & \multirow{2}{*}{$\begin{array}{c}\text { TATO } \\
\text { (kali) }\end{array}$} & & \multicolumn{4}{|c|}{ Kenaikan / Penurunan } \\
\cline { 5 - 8 } & & & Penj. Netto & $\%$ & Jumlah Aktiva & $\%$ \\
\hline 2014 & 4.075 .227 .281 & 4.749 .409 .795 & 0,86 & & & & \\
\hline 2015 & 4.237 .979 .643 & 4.565 .963 .576 & 0,93 & 162.752 .362 & 3,99 & $(183.446 .219)$ & $(3,86)$ \\
\hline 2016 & 4.524 .135 .762 & 4.820 .611 .941 & 0,94 & 286.156 .119 & 6,75 & 254.648 .365 & 5,58 \\
\hline 2017 & 4.453 .848 .569 & 5.385 .807 .878 & 0,83 & $(70.287 .193)$ & $(1,55)$ & 565.195 .937 & 11,72 \\
\hline 2018 & 5.001 .848 .767 & 6.138 .226 .584 & 0,81 & 548.000 .198 & 12,30 & 752.418 .706 & 13,97 \\
\hline
\end{tabular}

5. Fixed Asset Turnover PT. Surya Citra Media Tbk. Tahun 2014-2018 (dalam Ribuah Rupiah) :

\begin{tabular}{|c|c|c|c|c|c|r|c|}
\hline \multirow{2}{*}{ Tahun } & \multirow{2}{*}{ Penjualan Netto } & \multirow{2}{*}{ Aktiva Tetap } & \multirow{2}{*}{$\begin{array}{c}\text { FATO } \\
\text { (kali) }\end{array}$} & & \multicolumn{4}{|c|}{ Kenaikan / Penurunan } \\
\cline { 5 - 8 } & & & Penj. Netto & $\%$ & Aktiva Tetap & $\%$ \\
\hline 2014 & 4.075 .227 .281 & 763.737 .291 & 5,34 & & & & \\
\hline 2015 & 4.237 .979 .643 & 962.114 .344 & 4,40 & 162.752 .362 & 3,99 & 198.377 .053 & 25,97 \\
\hline 2016 & 4.524 .135 .762 & 966.766 .368 & 4,68 & 286.156 .119 & 6,75 & 4.652 .024 & 0,48 \\
\hline 2017 & 4.453 .848 .569 & 1.029 .335 .550 & 4,33 & $(70.287 .193)$ & $(1,55)$ & 62.569 .182 & 6,47 \\
\hline 2018 & 5.001 .848 .767 & 1.049 .625 .049 & 4,77 & 548.000 .198 & 12,30 & 20.289 .499 & 1,97 \\
\hline
\end{tabular}


6. Working Capital Turnover PT. Surya Citra Media Tbk. Tahun 2014-2018 (dalam Ribuah Rupiah) :

\begin{tabular}{|c|c|c|c|r|r|r|c|}
\hline \multirow{2}{*}{ Tahun } & \multirow{2}{*}{ Penjualan Netto } & \multirow{2}{*}{ Modal Kerja } & \multirow{2}{*}{\begin{tabular}{l} 
WCTO \\
\cline { 5 - 8 }
\end{tabular}} & & \multicolumn{4}{|c|}{ Kenaikan / Penurunan } \\
\hline 2014 & 4.075 .227 .281 & 2.386 .702 .130 & 1,71 & & & & \\
\hline 2015 & 4.237 .979 .643 & 1.983 .029 .871 & 2,14 & 162.752 .362 & 3,99 & $(403.672 .259)$ & $(16,91)$ \\
\hline 2016 & 4.524 .135 .762 & 1.961 .713 .269 & 2,31 & 286.156 .119 & 6,75 & $(21.316 .602)$ & $(1,07)$ \\
\hline 2017 & 4.453 .848 .569 & 1.965 .270 .095 & 2,27 & $(70.287 .193)$ & $(1,55)$ & 3.556 .826 & 0,18 \\
\hline 2018 & 5.001 .848 .767 & 2.622 .645 .887 & 1,91 & 548.000 .198 & 12,30 & 657.375 .792 & 33,45 \\
\hline
\end{tabular}

7. Inventory Turnover PT. Surya Citra Media Tbk. Tahun 2014-2018 (dalam Ribuah Rupiah) :

\begin{tabular}{|c|c|c|c|c|c|c|c|}
\hline \multirow{2}{*}{ Tahun } & Harga Pokok & Persediaan & ITO & \multicolumn{5}{|c|}{ Kenaikan / Penurunan } \\
\cline { 5 - 8 } & Penjualan & Rata-Rata & (kali) & HPP & $\%$ & Persd.Rata-rata & $\%$ \\
\hline 2014 & 2.147 .232 .219 & 605.858 .296 & 3,54 & & & & \\
\hline 2015 & 2.223 .431 .422 & 728.767 .138 & 3,05 & 76.199 .203 & 3,55 & 122.908 .843 & 20,29 \\
\hline 2016 & 2.520 .793 .898 & 877.301 .532 & 2,87 & 297.362 .476 & 13,37 & 148.534 .394 & 20,38 \\
\hline 2017 & 2.681 .737 .490 & 1.072 .283 .072 & 2,50 & 160.943 .592 & 6,38 & 194.981 .541 & 22,23 \\
\hline 2018 & 3.064 .152 .889 & 1.237 .335 .724 & 2,48 & 382.415 .399 & 14,26 & 165.052 .652 & 15,39 \\
\hline
\end{tabular}

8. Debt to Equity Ratio PT. Surya Citra Media Tbk. Tahun 2014-2018 (dalam Ribuah Rupiah) :

\begin{tabular}{|l|r|r|r|r|r|r|c|}
\hline \multirow{2}{*}{ Tahun } & \multirow{2}{*}{ Total Utang } & \multirow{2}{*}{ Total Ekuitas } & \multirow{2}{*}{$\begin{array}{c}\text { DER } \\
\end{array}$} & & \multicolumn{5}{|c|}{ Kenaikan / Penurunan } \\
\cline { 5 - 8 } & & & Total Utang & $\%$ & Total Ekuitas & $\%$ \\
\hline 2014 & 1.261 .541 .565 & 3.437 .768 .825 & 36,70 & & & & \\
\hline 2015 & 1.152 .287 .864 & 3.146 .363 .057 & 36,62 & $(109.253 .701)$ & $(8,66)$ & $(291.405 .768)$ & $(8,48)$ \\
\hline 2016 & 1.115 .203 .785 & 3.705 .408 .156 & 30,10 & $(37.084 .079)$ & $(3,22)$ & 559.045 .099 & 17,77 \\
\hline 2017 & 980.414 .618 & 4.405 .393 .260 & 22,25 & $(134.789 .167)$ & $(12,09)$ & 699.985 .104 & 18,89 \\
\hline 2018 & 1.035 .274 .069 & 5.102 .952 .515 & 20,29 & 54.859 .451 & 5,60 & 697.559 .255 & 15,83 \\
\hline
\end{tabular}

9. Debt to Asset Ratio PT. Surya Citra Media Tbk. Tahun 2014-2018 (dalam Ribuah Rupiah) :

\begin{tabular}{|c|r|r|r|r|r|r|c|}
\hline \multirow{2}{*}{ Tahun } & \multirow{2}{*}{ Total Utang } & \multirow{2}{*}{ Total Aktiva } & \multirow{2}{*}{\begin{tabular}{c} 
DAR \\
\cline { 5 - 8 }
\end{tabular}} & & \multicolumn{4}{|c|}{ Kenaikan / Penurunan } \\
\cline { 5 - 8 } & & & Total Utang & $\%$ & Total Aktiva & $\%$ \\
\hline 2014 & 1.261 .541 .565 & 4.749 .409 .795 & 26,56 & & & & \\
\hline 2015 & 1.152 .287 .864 & 4.565 .963 .576 & 25,24 & $(109.253 .701)$ & $(8,66)$ & $(183.446 .219)$ & $(3,86)$ \\
\hline 2016 & 1.115 .203 .785 & 4.820 .611 .941 & 23,13 & $(37.084 .079)$ & $(3,22)$ & 254.648 .365 & 5,58 \\
\hline 2017 & 980.414 .618 & 5.385 .807 .878 & 18,20 & $(134.789 .167)$ & $(12,09)$ & 565.195 .937 & 11,72 \\
\hline 2018 & 1.035 .274 .069 & 6.138 .226 .584 & 16,87 & 54.859 .451 & 5,60 & 752.418 .706 & 13,97 \\
\hline
\end{tabular}

10. Gross Profit Margin PT. Surya Citra Media Tbk. Tahun 2014-2018 (dalam Ribuah Rupiah) :

\begin{tabular}{|c|c|c|c|r|r|r|c|}
\hline \multirow{2}{*}{ Tahun } & \multirow{2}{*}{ Laba Kotor } & \multirow{2}{*}{ Penjualan } & \multirow{2}{*}{\begin{tabular}{c} 
GPM \\
\cline { 5 - 8 }
\end{tabular}} & & \multicolumn{4}{|c|}{ Kenaikan / Penurunan } \\
\hline 2014 & 1.927 .995 .062 & 4.075 .227 .281 & 47,31 & & & & \\
\hline 2015 & 2.014 .548 .221 & 4.237 .979 .643 & 47,54 & 86.553 .159 & 4,49 & 162.752 .362 & 3,99 \\
\hline 2016 & 2.003 .341 .864 & 4.524 .135 .762 & 44,28 & $(11.206 .357)$ & $(0,56)$ & 286.156 .119 & 6,75 \\
\hline 2017 & 1.772 .111 .079 & 4.453 .848 .569 & 39,79 & $(231.230 .785)$ & $(11,54)$ & $(70.287 .193)$ & $(1,55)$ \\
\hline 2018 & 1.937 .695 .878 & 5.001 .848 .767 & 38,74 & 165.584 .799 & 9,34 & 548.000 .198 & 12,30 \\
\hline
\end{tabular}


11. Net Profit Margin PT. Surya Citra Media Tbk. Tahun 2014-2018 (dalam Ribuah Rupiah) :

\begin{tabular}{|c|c|c|c|r|r|r|c|}
\hline \multirow{2}{*}{ Tahun } & Laba Setelah & \multirow{2}{*}{ Penjualan } & \multirow{2}{*}{\begin{tabular}{c} 
NPM \\
\cline { 5 - 8 }
\end{tabular}} & Pajak (EAT) & & \multicolumn{4}{|c|}{ Kenaikan / Penurunan } \\
\hline 2014 & 1.457 .696 .437 & 4.075 .227 .281 & 35,77 & & & & \\
\hline 2015 & 1.524 .996 .907 & 4.237 .979 .643 & 35,98 & 67.300 .470 & 4,62 & 162.752 .362 & 3,99 \\
\hline 2016 & 1.511 .144 .612 & 4.524 .135 .762 & 33,40 & $(13.852 .295)$ & $(0,91)$ & 286.156 .119 & 6,75 \\
\hline 2017 & 1.317 .748 .064 & 4.453 .848 .569 & 29,59 & $(193.396 .548)$ & $(12,80)$ & $(70.287 .193)$ & $(1,55)$ \\
\hline 2018 & 1.475 .042 .200 & 5.001 .848 .767 & 29,49 & 157.294 .136 & 11,94 & 548.000 .198 & 12,30 \\
\hline
\end{tabular}

12. Return on Asset PT.Surya Citra Media Tbk. Tahun 2014-2018 (dalam Ribuah Rupiah):

\begin{tabular}{|c|c|c|c|c|c|c|c|}
\hline \multirow{2}{*}{ Tahun } & Laba Sebelum & \multirow{2}{*}{ Total Aktiva } & \multirow{2}{*}{\begin{tabular}{c} 
ROA \\
\cline { 5 - 8 }
\end{tabular}} & \multicolumn{5}{|c|}{ Kenaikan / Penurunan } \\
\hline 2014 & 1.927 .995 .062 & 4.749 .409 .795 & 40,59 & & & & \\
\hline 2015 & 2.014 .548 .221 & 4.565 .963 .576 & 44,12 & 86.553 .159 & 4,49 & $(183.446 .219)$ & $(3,86)$ \\
\hline 2016 & 2.003 .341 .864 & 4.820 .611 .941 & 41,56 & $(11.206 .357)$ & $(0,56)$ & 254.648 .365 & 5,58 \\
\hline 2017 & 1.772 .111 .079 & 5.385 .807 .878 & 32,90 & $(231.230 .785)$ & $(11,54)$ & 565.195 .937 & 11,72 \\
\hline 2018 & 1.937 .695 .878 & 6.138 .226 .584 & 31,57 & 165.584 .799 & 9,34 & 752.418 .706 & 13,97 \\
\hline
\end{tabular}

13. Return on Equity PT. Surya Citra Media Tbk. Tahun 2014-2018 (dalam Ribuah Rupiah) :

\begin{tabular}{|c|c|c|c|c|c|c|c|}
\hline \multirow{2}{*}{ Tahun } & \multirow{2}{*}{$\begin{array}{l}\text { Laba Sebelum } \\
\text { Pajak (EAT) }\end{array}$} & \multirow{2}{*}{ Modal Saham } & \multirow{2}{*}{$\begin{array}{c}\mathrm{ROE} \\
(\%)\end{array}$} & \multicolumn{4}{|c|}{ Kenaikan / Penurunan } \\
\hline & & & & EAT & $\%$ & Modal Saham & $\%$ \\
\hline 2014 & 1.457 .6 & & 143,90 & & & & \\
\hline 2015 & 1.52 & & 151,08 & & 4,62 & & $(0,36)$ \\
\hline 2016 & 1.51 & 1.0 & 149,66 & 95) & $(0,91)$ & & 0,03 \\
\hline 2017 & 1.317 & 1.009 .712 .874 & 130,51 & $(193.396 .548)$ & $(12,80)$ & 0 & 0,00 \\
\hline 2018 & 1.475 .042 .200 & 1.009 .811 .145 & 146,07 & 157.294 .136 & \begin{tabular}{|l|}
11,94 \\
\end{tabular} & 98.271 & 0,01 \\
\hline
\end{tabular}




\section{E. PENUTUP}

\section{Kesimpulan}

Berdasarkan analisis data keuangan PT. Surya Citra Media Tbk. dari tahun 2014 sampai dengan tahun 2018 yang dibahas diatas, maka keseluruhan hasil analisa peneliti rangkum seperti tabel dibawah ini :

\begin{tabular}{|l|c|c|c|c|c|c|}
\hline \multicolumn{1}{|c|}{ Ratio / Year } & $\mathbf{2 0 1 4}$ & $\mathbf{2 0 1 5}$ & $\mathbf{2 0 1 6}$ & $\mathbf{2 0 1 7}$ & $\mathbf{2 0 1 8}$ & Average \\
\hline \hline Liquidity Ratio & $\mathbf{( \% )}$ & $\mathbf{( \% )}$ & $\mathbf{( \% )}$ & $\mathbf{( \% )}$ & $\mathbf{( \% )}$ & $(\boldsymbol{\%})$ \\
\hline Current Ratio & 391,76 & 330,46 & 298,06 & 364,39 & 426,14 & 362,16 \\
\hline Quick Ratio & 239,12 & 250,77 & 228,47 & 261,34 & 308,91 & 257,72 \\
\hline Cash Ratio & 152,64 & 79,69 & 45,91 & 31,41 & 103,16 & 82,56 \\
\hline Activity Ratio & $\mathbf{( k a l i )}$ & $\mathbf{( k a l i )}$ & $\mathbf{( k a l i )}$ & $\mathbf{( k a l i )}$ & $\mathbf{( k a l i )}$ & $(\mathbf{k a l i})$ \\
\hline Total Asset Turnover & 0,86 & 0,93 & 0,94 & 0,83 & 0,81 & 0,87 \\
\hline Fixed Asset Turnover & 5,34 & 4,40 & 4,68 & 4,33 & 4,77 & 4,70 \\
\hline Working Capital Turnover & 1,71 & 2,14 & 2,31 & 2,27 & 1,91 & 2,06 \\
\hline Inventory Turnover & 3,54 & 3,05 & 2,87 & 2,50 & 2,48 & 2,89 \\
\hline Solvability Ratio & $\mathbf{( \% )}$ & $\mathbf{( \% )}$ & $\mathbf{( \% )}$ & $\mathbf{( \% )}$ & $\mathbf{( \% )}$ & $(\boldsymbol{\%})$ \\
\hline Debt to Equity Ratio & 36,70 & 36,62 & 30,10 & 22,25 & 20,29 & 29,19 \\
\hline Debt to Asset Ratio & 26,56 & 25,24 & 23,13 & 18,20 & 16,87 & 22,00 \\
\hline Profitability Ratio & $\mathbf{( \% )}$ & $\mathbf{( \% )}$ & $\mathbf{( \% )}$ & $\mathbf{( \% )}$ & $\mathbf{( \% )}$ & $(\boldsymbol{\%})$ \\
\hline Gross Profit Margin & 47,31 & 47,54 & 44,28 & 39,79 & 29,49 & 41,68 \\
\hline Nett Profit Margin & 35,77 & 35,98 & 33,40 & 29,59 & 29,49 & 32,85 \\
\hline Return on Asset & 40,59 & 44,12 & 41,56 & 32,90 & 31,57 & 38,15 \\
\hline Return on Equity & 143,90 & 151,08 & 149,66 & 130,51 & 146,07 & 144,24 \\
\hline
\end{tabular}

Dari rangkuman rasio-rasio diatas, maka dapat diambil kesimpulan bahwa kinerja keuangan PT. Surya Citra Media Tbk. berdasarkan analisis laporan keuangan pada tahun 2014-2018 sebagai berikut :

1. Berdasarkan hasil rasio likuiditas, walaupun current ratio pada tahun 2015 dan 2016 mengalami penurunan, namun berturut-turut pada tahun 2017 dan 2018 mengalami kenaikan lagi sehingga rata-rata current ratio untuk periode 2014-2018 sebesar $362,16 \%$ sehingga bisa disimpulkan bahwa keuangan perusahaan sangat sehat, karena berdasarkan prinsip kehati-hatian standar besarnya current ratio minimal sebesar $200 \%$ atau $2: 1$.

Begitu pula dengan quick ratio, rata-rata untuk periode 2014-2018 hasilnya sebesar $257,72 \%$ sehingga besaran utang lancar cukup dijamin dengan jumlah aktiva lancar persediaan. Cash ratio untuk periode 2014-2018 rata-rata hasil rasionya sebesar $82,56 \%$ hal ini masih baik karena standarnya sebesar $50 \%$.

2. Hasil aktivitas rasio juga cukup baik, selama periode tahun 2014-2018 untuk total asset turnover stagnan antara 0,81-0,94 kali, sedangkan fixed asset turnover walaupun mulai tahun 2015 mengalami penurunan namun secara rata-rata penurunan tersebut tidak signifikan. Hasil rasio working capital turnover juga cukup baik, dimana secara rata-rata modal kerja menghasilkan dua kali lipat penjualan. Begitu pula dengan rasio inventory turnover hasilnya sangat baik dimana persediaan yang bisa menghasilkan penjualan hampir tiga kali lipat.

3. Rasio solvabilitas untuk periode $2014-2018$, debt to equity ratio mengalami penurunan secara terus menerus dimulai dari tahun 2015 sampai dengan tahun 2018, sehingga hal ini mengindikasikan bahwa kinerja keuangan perusahaan dalam kondisi baik dimana besarnya hutang tidak melebihi jumlah modal (ekuitas). Begitu pula dengan debt to asset ratio mengalami penurunan yang signifikan, hal ini menyimpulkan bahwa 
kinerja keuangan perusahaan sangat baik, dimana total aset (aktiva) dari tahun 20142018 mengalami penambahan (peningkatan), akan tetapi jumlah hutang justru mengalami penurunan, hal ini mengindikasikan bahwa peningkatan aktiva tidak mutlak dibiayai oleh hutang, akan tetapi sebagian besar justru dibiayai dari laba atau modal internal perusahaan.

4. Kemampuan perusahaan dalam menghasilkan laba untuk periode 2014-2018 masih dalam kondisi baik, walaupun rasio gross profit margin dan net profit margin dari tahun 2014 sampai dengan 2018 mengalami penurunan, akan tetapi rata-rata rasionya masih diatas $20 \%$ atau dengan kata lain secara average setiap tahunnya operasional perusahaan masih mendapatkan laba diatas $20 \%$ dari penjualan. Begitu pula dengan hasil rasio return on asset dan return on equity, mengindikasikan kinerja keuangan perusahaan sangat baik, dimana aset (aktiva) bisa menghasilkan laba diatas $30 \%$, bahkan modal perusahaan menghasilkan laba diatas 140\%.

\section{Keterbatasan Penelitian}

Dalam penelitian ini, penulis menyadari akan adanya keterbatasan dalam melakukan penelitian, dimana di Indonesia banyak perusahaan jasa penyiaran televisi, tetapi yang sudah melantai ( $g o$ public) di Bursa Efek Indonesia baru dua, yaitu PT. Surya Citra Media Televisi Tbk. (SCMA) dan PT. Media Nusantara Citra Tbk. (MNCN), sehingga di dalam penelitian tidak bisa membuat standar rasio keuangan untuk perusahaan sejenis.

\section{Saran}

Kinerja keuangan PT. Surya Citra Media Tbk. untuk periode tahun 2014 sampai dengan 2018 sudah cukup baik, hal ini perlu dipertahankan dan bahkan kalau perlu harus ditingkatkan. Namun seiring dengan perkembangan teknologi penyiaran menuntut pelaku industri jasa penyiaran khususnya televisi untuk melakukan pengembangan strategi, diantaranya dengan memberikan konten terbaik, informasi maupun berbagai siaran yang inovatif.

Disamping itu dengan semakin mudah dan murahnya akses layanan internet di Indonesia, maka pemirsa televisi lebih condong menonton siaran televisi melalui gawainya, untuk itu manajemen PT. Surya Citra Media Tbk. sudah harus memikirkan bagaimana caranya agar perusahaan tetap bertahan dan tetap eksis, maka siaran televisi dibawah naungan perusahaan ini mudah diakses melalui telepon genggam seperti yang sudah dilakukan oleh Netflix, iFlix, Hulu, Amazon Prime Video, Sling TV, HBO, hingga Youtube TV.

\section{DAFTAR PUSTAKA}

Abdul Kadim, K., \& Nardi Sunardi, S. (2018). Determinant Of Company's Likuidity And It's Implications On Financial's Performance Of Ritail Trade Company's In Indonesia At The Period Of 2008-2017. Global and Stockhastic Analysis, 5(7), 235-247.

Abdul Kadim, K., \& Nardi, S. (2018). Eviews Analysis: Determinant Of Leverage And Company's Performance. Global and Stochastic Analysis (GSA), 5(7), 249-260.

Fahmi, Irham, 2012. Analisa Laporan Keuangan. Cetakan kedua. Bandung: Alfabeta.

Handoko, T., Hani, 1998. Manajemen dan Sumber Daya Manusia. Yogyakarta: Liberty.

Hasibuan, Malayu, 2000. Manajemen Sumber Daya Manusia. Edisi Revisi. Jakarta: PT. Bumi Aksara.

Ikatan Akuntan Indonesia. 2002. Standar Akuntansi Keuangan. Jakarta: Salemba Empat.

Kasmir. 2014. Analisis Laporan Keuangan. Edisi Pertama, Cetakan Ketujuh. Jakarta: PT. Rajagrafindo Persada. 
Lutfi, A. M., \& Sunardi, N. (2019). Pengaruh Current Ratio (Cr), Return On Equity (Roe), Dan Sales Growth Terhadap Harga Saham Yang Berdampak Pada Kinerja Keuangan Perusahaan (Pada Perusahaan Manufaktur Sektor Makanan Dan Minuman Yang Terdaftar Di Bursa Efek Indonesia). Jurnal SEKURITAS (Saham, Ekonomi, Keuangan dan Investasi), 2(3), 83-100.

Mulyadi, 2012. Akuntansi Biaya. Yogyakarta: UPP STIM YKPN.

Munawir, S. 2004. Analisa Laporan Keuangan. Edisi ke-4. Cetakan ke-11. Yogyakarta: Liberty.

Puspitaningtyas, Dionisia Domasrani, 2014. Analisa laporan Keuangan Untuk menilai Kinerja Keuangan Perusahaan PT. Gudang Garam Tbk. Skripsi. Program Studi Akuntansi, Fakultas Ekonomi, Universitas Sanata Sharma, Yogyakarta.

Rudianto. 2013. Akuntansi Manajemen. Jakarta: Erlangga.

Sawir, Agnes. 2001. Analisis Kinerja Keuangan dan Perencanaan Keuangan Perusahaan. Cetakan kedua. Jakarta: PT. Gramedia Pustaka Utama.

Sodikin, Slamet Sugiri, dan Riyono, Bogat Bagus. 2014. Akuntansi Pengantar 1. Edisi Ke9. Cetakan Pertama. Yogyakarta: UPP STIM YKPN.

Subramanyam, K.R., dan Wild, John J. (2014). Analisis Laporan Keuangan. Edisi Sepuluh, Buku Satu. Jakarta: Salemba Empat.

Sunardi, N. (2018). Analisis Du Pont System Dengan Time Series Approach (Tsa) Dan Cross Sectional Approach (Csa) Dalam Penilaian Kinerja Keuangan Perusahaan (Studi Pada Industri Konstruksi (BUMN) di Indonesia Yang Listing di BEI Tahun 2013-2017). Jurnal SEKURITAS (Saham, Ekonomi, Keuangan dan Investasi), 1(4).

Sunardi, N. (2018). Analisis Risk Based Bank Rating (RBBR) Untuk Mengukur Tingkat Kesehatan Bank Syariah Di Indonesia. JIMF (Jurnal IImiah Manajemen Forkamma), 1(2).

Suryanto, Wirawan, 2019. Pengaruh Return on Assets, Current Ratio, Total Asset Turn Over, dan Quick Ratio Terhadap Earning Per Share Serta Dampaknya Terhadap Dividen Payout Ratio. Jurnal Sekuritas, Vol.2, No.3, Mei 2019.

Team Teaching, 2019. Modul Analisis Laporan Keuangan. Tangerang Selatan: Fakultas Ekonomi, Universitas Pamulang. 